\title{
Ethnologies
}

\section{Of Ideas and Objects}

\section{Andrée Gendreau}

Volume 34, numéro 1-2, 2012

URI : https://id.erudit.org/iderudit/1026148ar

DOI : https://doi.org/10.7202/1026148ar

Aller au sommaire du numéro

Éditeur(s)

Association Canadienne d'Ethnologie et de Folklore

ISSN

1481-5974 (imprimé)

1708-0401 (numérique)

Découvrir la revue

Citer cet article

Gendreau, A. (2012). Of Ideas and Objects. Ethnologies, 34(1-2), 133-147.

https://doi.org/10.7202/1026148ar

\section{Résumé de l'article}

Cet article propose un regard d'ensemble comparatif sur l'histoire des musées en Europe et en Amérique du Nord, de leurs origines à leurs transformations les plus récentes. Il met en évidence sur l'évolution distincte des musées en Amérique du Nord par rapport à leurs homologues européens, avec leur accent sur la dimension ludique et les liens étroits qu'ils développent avec les communautés locales. Il montre également comment les musées au Québec, et dans l'ensemble du Canada, ont plutôt tendance à se concentrer davantage sur les idées par rapport aux musées en Europe, le Musée de la civilisation en étant un parfait exemple. Les musées nord-américains ont ainsi démontré la capacité de s'adapter aux besoins spécifiques des communautés en se développant comme des institutions ouvertes et souples, capables de préserver le patrimoine, de parler aux citoyens, de transmettre des savoirs ou mettre simplement de donner vie aux cultures passées et présentes.
Ce document est protégé par la loi sur le droit d'auteur. L'utilisation des services d'Érudit (y compris la reproduction) est assujettie à sa politique d'utilisation que vous pouvez consulter en ligne.

https://apropos.erudit.org/fr/usagers/politique-dutilisation/ 


\section{Of IDEAS AND OBJects}

\section{Andrée Gendreau}

Musée de la civilisation

\section{Introduction}

The rapid transformation of museums over the past twenty years has given rise to a wealth of debate and interpretation, fueling a three-centuryold squabble that Andreas Huyssen refers to as "the battle against the museum." (Huyssen 1995: 13). The Quarrel between the Ancients and the Moderns, among other things against museumification, continues to this day, accusing fingers pointed no longer at the thesaurization of works and objects, their out-of-context display, or the excluding effect of museums, but rather at the mummification of public spaces, certain cities or parts of them, and, it is tempting to add, life itself.

As the dying embers of age-old debates are being fanned back to life, the network of museums is rapidly expanding and carving out a place for itself in the contemporary world of mass media. Communication, theatrical staging techniques, the exchange and circulation of works, and the plethora of international rapports are clearly heaping pressure on museums, which are now among the most vibrant and productive cultural institutions in the Western world. Millions of tourists and local residents visit them daily, to such an extent that these institutions - as much for their variety (historical society museums, art museums, science museums, botanical gardens, planetariums, etc.) as their inclusion in tourist itineraries - have become an integral part of urban, regional, and government strategies to combine leisure and education, while stimulating the economy. In addition to museumification, the institutions are now also accused of overmediatization and of pursuing a market-driven approach based on audience studies and marketing.

How do we explain this dichotomy between the public's enthusiasm for museums and the enduring aversion of certain intellectuals to these same 
institutions? Furthermore, how can we explain this ongoing opposition? Is it possible that the museum itself simultaneously creates two contradictory trajectories that generate both museummania and museumphobia? Or could it be that, far from contradicting each other, these trajectories instead intersect to form a rich and promising dialectic? If this were the case, the place of today's museums in a world of mass media would impact not only the economy and the education of the masses, but also the development of scientific knowledge and the transmission of our heritage from one generation to the next. I maintain this to be the case and that museums always have been - and to this day continue to be - repositories of knowledge, instruments of heritage protection, and sources of inspiration and learning for visitors. If certain museums act as mediators between knowledge and society, others build bridges between artists and the public, or between elders and the next generation. The objects of transmission, poles of exchange (transmitter and receiver), or even the ways objects, artifacts, or works are used vary depending on the period and culture, but their relative role in heritage protection and knowledge development remain stable. The recent definitions put forward by the ICOM (Barcelona, 2001) and the CMA (Québec City, 2004), which include the protection of intangible heritage, speak volumes in this regard, confirming the museum's role as mediator, a role that dates back to its very creation.

In this paper, I will briefly review the birth of the museum to demonstrate that the three functions cited above have truly existed since the time of its origins. Firstly, I will emphasize the museum's scientific function and the relationship between this role and heritage conservation. Next, I will recall the importance of the museum's role in the world of media to then, in a second part, cast our gaze upon the transformations that have occurred in past decades and their consequences for the institution's classic mission. Examples from across Canada will be cited to support my arguments. I hope to show how, particularly in the New World and specifically among Native peoples, the museum became a conduit for the transmission of traditional knowledge. Finally, in a third part, the Musée de la civilisation de Québec will serve as a case study to illustrate the phenomenon of museology development over the past 20 years, particularly as concerns the exhibiting of ideas, concepts, and ways of life. A recent exhibit on democratic culture will illustrate the link between the exhibit, research, and a specific example of mediation of contemporary intangible heritage. 


\section{Public museums: Science, collections, and mediation}

The evolution of the museum as an institution is marked by two main periods - modernity and the current age known as postmodernity. These were preceded by a period called pre-museology, a time when curiosity cabinets came into fashion, cropping up all over Europe until the 17th century. We won't dwell here on the scientific and geographic discoveries of the Renaissance that marked a worldwide shift and an opening of the European to the Other. However, it is worth noting that this Other was at first perceived as an object of curiosity, and later as an entity, but only took on meaning in a context of political, economic, and religious strategies. In this regard, the parallel between the Other's scriptural narrative discourse (travel diaries) and the collections is striking. The analyses of Todorov (1982), Centlivres (1982), Leclerc (1979), and others are highly telling in this regard and merit closer attention. But one could not yet speak of museums and even less of museums of man. For that, two conditions were necessary: openness to the public and the advent of the human sciences.

The Age of Enlightenment, more particularly the French Revolution, gave museums the legal and material forms through which we know them today. Among other things, it was up to museums to bridge private and public spheres, both from the point of view of material collections (protection, exhibits) and the transmission of symbolic values associated with them. The roles of curator, classifier, and educator henceforth became an integral part of the mission of any museum. As for the development of knowledge, certain disciplines such as art history or anthropology would reap the benefits from the establishment of museums and their field of discipline. In this regard, the creation of the Museum of Man speaks volumes. Given our common interest, it will serve as an example to illustrate the role museums have had in structuring thought in the human sciences. We will also briefly see how the museum assumed its new role as mediator for citizens, before touching briefly on the world of North American museology.

\section{Towards a Museum of Man}

For the human sciences to develop and museums of man to arise, the old epistemology based strictly on a narrative system of individual observation and the gathering of diverse objects, like those on display in curiosity cabinets, had to give way to an altogether new way of thinking - one that was ordered and could be shared with others - with one sole focus: man. Protocols leading to a uniform system of observation and collection, an 
ability to study, analyze, and ensure continuity - in short, specific social and institutional conditions - became necessary to shape the way naturalists, botanists, cosmographers, and ecclesiastics in the field looked at the world.

The publication of Les Mémoires de la société des Observateurs de l'homme (1799-1805) by Jauffret and Girando (Copans and Jamin 1978), addressed this need to standardize data collection methods. It was accompanied by a vague institutional plan aimed at ensuring the long term viability of research and studies. The introduction gave voice to the need to create a "special Museum" to supplement the Observers' documents with:

\footnotetext{
Various objects relating to the work in question, notably all the products of the industry of savages, all the objects of comparison that can serve to promote knowledge of the many varieties of the human species, as well as the mores and customs of ancient and modern peoples.
}

With the publication of this work, not only was a new science born with its own field of study and body of specific investigative methods and techniques, but the concept of the reference object - an idea that took definitive shape with the publication of the 1925 essay by Marcel Mauss entitled "The Gift" - and the vision of the total social fact were already provisionally included. This in many regards significant work would forever change the meaning of the anthropological object, its representative value and documentary interest forever displacing its intrinsic value (esthetics, rarity, etc.). Henceforth, its only significance would be as part of a whole (the collection) and in relation to society and culture. In other words, the tangible object only completely exists within the intangible. Although the opposite is not always true, it can nevertheless be said that the tangible object broadly supports the intangible and that it is sometime even necessary to its fulfillment. We need only think, among other things, of certain types of music and cooking, and of certain religious orders.

\section{Museums and mediation}

Let us return briefly to the museum of the Revolution, which was quickly called upon to meet the growing public demand for "cultivated leisure activities." Associated with another newly formed institution, the French lycée, museums offered conferences and courses. Their success quickly made them one of the leading champions of individual critical reasoning (Habermas 1978), in addition to the Clubs and the Press. Thus mediation between the state and citizens through the transfer of scientific and artistic knowledge was added to their original mission. Never again 
would this new mediating - or educational - function be renounced. I would, however, go as far as to say that the late $20^{\text {th }}$ century would see the addition of yet another role, that of transmitting memory, a phenomenon not unrelated in my opinion to postmodernist loss of memory.

Lastly, we would be remiss to discuss the modern museum without mentioning the importance of the American influence, a precursor of the contemporary mass media museum. In North America, both in Canada as the United States (Dubé and Montpetit 1991), museums have always been viewed as much as places of leisure as places of research and education, to such a degree that Boas was led to state that the objective of museums was threefold:

They may be institutions designed to furnish healthy entertainment, they may be intended for instruction and they may be intended for promotion of research. (Boas 1907:921)

On leisure, he goes on to say,

The value of the museum as a resort for popular entertainment must not be underrated, particularly in a large city, where every opportunity that is given to the people to employ their leisure time in healthy and stimulating surroundings should be developed, where every attraction that contracts the influence of the saloon and the race-track is of great social importance. (Boas 1907: 921-22)

The museum was already well on the way to the postmodern age.

\section{The postmodern museum}

Since the 1980s, the world of museums has undergone a sea change. First came a quite extraordinary proliferation of museums, the "Museum Boom." In Canada alone, 2,500 museums stretch from the Yukon to Newfoundland. The museum map encompasses villages, reserves, and natural parks in addition to major cities like Vancouver, Toronto, and Montreal. Approximately 59 million people visit them each year - almost the double of the population of Canada! They are responsible for salaries and wages totaling over $\$ 650,000$, employ some 24,000 people, and are supported by 55,000 volunteers and 300,000 friends of museums. For its part, Musée de la civilisation de Québec welcomes up to 600,000 visitors a year - the equivalent of the entire population of Québec City. This enthusiasm for museums has several benefits, including greater openness to the rest of the world, as well as to cultural diversity and other people. Special interest 
museums have sprung up. Thus museums of gold, energy, Indians, science, war, dolls, bees, etc. have their share of visitors alongside more traditional museums. Each and every region, cultural group, or association wants its "own" museum or hopes to be portrayed by such an institution, if only for the duration of an exhibit. Indeed, at first blush, that's all it appears to be: portrayal. However, closer inspection reveals it also to be a matter of social inclusion, of documenting and preserving memory, and of transmitting culture and knowledge.

Museums provide showcases in which to exhibit, explain, and illustrate the importance of a phenomenon, group, or story. Through them, they forge ties between their exhibit partners and surrounding communities. But more than that, museums hold out the promise of a future, by linking past to future in this transient present. Recounting memories in a museum keeps the memories alive. By recording the past actions of a group - be it ethnic, cultural, or even a work group (we need only think of Cité de l'Énergie in Mauricie, which is bringing the golden age of Québec electrification back to life) - the survival of this human act is assured, at least in its symbolic dimension. But museums don't just dwell on successes: they are equally concerned with presenting the traces and voices of violence, destruction, war, and ethnocide. Memory therefore steps in to encourage the individual to take on a social role of survival or reparation. The museum in its role as social actor collects and documents evidence of events, life stories, or endangered traditions so as to transmit a heritage, however easy or hard this heritage may be to assume, to enlighten consciences, to act, and to take part in change. Its goal is to move, educate, and mobilize. In the process, it becomes a place to meet and exchange ideas, a place for culture to find expression.

The functions of the postmodern museum have adapted to the growing needs of the public to find life and value in these institutions. Thus, at the annual meeting of the Canadian Museums Association in 2004, the association adopted a new, broader definition of what constitutes a museum, in particular to better reflect the reality of museums focused on the community and the transmission of intangible values. It reads as follows:

Museums are institutions created in the public interest. They engage their visitors, foster deeper understanding, and promote the enjoyment and sharing of authentic cultural and natural heritage. Museums acquire, preserve, research, interpret, and exhibit the tangible and intangible evidence of society and nature. As educational institutions, museums provide a physical forum for critical inquiry and investigation. 
Museums are permanent, not-for-profit institutions whose exhibits are regularly open to the general public. This definition encompasses institutions that pursue similar objectives and accomplish most or some of a museum's functions. Accordingly, the following are also recognized as museums:

Exhibition places such as art galleries and science and interpretation centers

Institutions with plant and animal collections and displays, such as botanical gardens, biodomes, zoos, aquariums, and insectariums

Cultural establishments that facilitate the preservation, continuation, and management of tangible and intangible living heritage resources, such as keeping houses and heritage centers

Natural, archaeological, ethnographic, and historical monuments and sites

\section{The broader role of First Nations museums}

In this regard, First Nations museums in Quebec and across Canada are performing miracles. Often small institutions with few resources and usually located far from urban centers, they are nonetheless deeply rooted in their communities, acting in many ways as a social lever. Confronted with the loss of traditional ways of life, the growing divide between young and old, the erosion - or complete extinction - of language, and, all too often, poverty, ignorance, and other social ills that result from the above, they are relentless in their efforts to rebuild a social identity and sense of pride that have often been left battered and bruised. To this end, they use the museum as a place of assembly, welcome, and exchange, adapting it to their own needs and traditions. In certain instances, the museum may even be associated with the idea of a shared home, a traditional way of life among many of the First Nations indigenous to Quebec. In this respect, the Shaputuan museum (the home of the Innu), located close to a shopping mall, a busy area if ever there was one, is a good example. Firmly rooted in its Côte-Nord community, it has made it its mission to "better publicize and [...] spread Innu culture" by being "a place of assembly, meeting, dialog, and sharing." To truly fulfill its objective of being a "tool of social change" and to contribute "concretely to self-awareness," it relies on the "active participation of Innu elders and artists" to express "a contemporary, objective, and lucid vision of past and current Innu realities". With its experience in welcoming visitors, the museum was then able to broaden the 
Shaputuan mission by developing partnerships with organizations working to protect the Innu language. Thus it is home to Institut culturel et éducatif montagnais, which holds language classes for Innu children, many of whom increasingly have trouble speaking their native tongue. The museum is also coauthoring a dictionary aimed at standardizing this spoken language. In August 2006, it held a modern art symposium, exhibiting the works of not only First Nations artists, but also francophone and anglophone whites. It is also working closely with the neighboring Musée de Sept-Îles on all sorts of activities for Côte-Nord communities.

At the Musée des Abénakis in Odanak in the Nicolet-Yamaska region of Central Quebec, the picture is very different, but interest in and openness towards the nation remains the same. The museum is not faced with the challenges of a recent nomadic past. The Abenaki, francophones for the most part, settled along the St. Lawrence river towards the end of the $17^{\text {th }}$ century. They became urban dwellers around the same time as their French Canadians neighbors. The museum is, of course, open to all - tourists and the local population alike - but the activities available are clearly focused on a better understanding of traditional culture and on conserving elements of survival. Objects are used as witnesses or actual tools to illustrate and give form to the tales, legends, and dances the museum conveys. Although conservation, documentation, and collection presentation underpin the museum's activities, education is the cornerstone of its mission. Traditional legends are brought to life, study sessions present aspects of traditional lifestyles (food and cooking, forest survival, crafts) and Amerindian spirituality. The museum also welcomes Amerindian dance companies and singers for public or private performances. In each case, and whenever possible (which it isn't always), artifacts are used to give form to the experiences or learnings. For example, the freshwater drum on display enables visitors to visualize the object spoken about in a tale. Conversely, the musicians and dancers accompanied by the freshwater drum let its peculiar sound reverbrate around the museum, giving concrete expression to the sound "that resonates like a uterus." The exchange works in both directions as life reclaims its rightful place. Together, the activities and exhibits thus allow the museum to fulfill its role as a pivot between traditional cultural heritage and contemporary life. As museum director Jacqueline O'Bomsawin notes, "Here the living pass on a still-living culture. We don't have any mummies on display, only things that are alive."

These two examples certainly do not fully express the variety of experiences on offer at Amerindian and Inuit museums, each of them 
having practices specific to their own communities. I am sorry I cannot name them all, if only for the musicality of their names, but that is beyond the scope of our subject. Instead, I would simply mention that the same phenomenon is observable in many places in English Canada. The museums cooperate closely with the First Nations Confederacy of Cultural Education Centers (FNCCEC), which aids in the implementation and development of a number of First Nations education programs. I should also mention the Buffalo Nations Luxton Museum, whose mission concerns the First Nations of the Plains. Artifacts, exhibits, dioramas, shows, storytelling, and legends are all used as teaching methods. There too, theater and dance companies are called upon to put on performances and carry out demonstrations as part of extremely popular traditional craft workshops. They have also developed a section on traditional medicine, enabling them to document and transmit knowledge and practices. Due to the interest generated in such matters, they have teamed up with the Red Cross in an effort to prevent the spread of HIV among young people. The board of directors, composed of various members of First Nations communities in Alberta, has also taken on the mantle of enhancing understanding between peoples through the dissemination of knowledge. Their website provides much more information on the subject.

By way of these few examples, I hoped to illustrate the active role museums play in developing the social fabric of their communities while transmitting tangible and intangible heritage. Such museums tend to present themselves more as cultural or community centers, welcoming partners and collaborators to provide First Nations people with cultural and educational services adapted to their needs. In certain cases, as we have seen, the welcome extends beyond the walls of the museum right into people's lives, wherever they may be, at school or elsewhere. Rather than restricting themselves to a narrow definition of what they represent - and therefore are mandated to do - First Nations museums have been in the vanguard of openness, creativity, and attentiveness to the local population. Once again, many examples spring to mind to illustrate our point, such as the U'Mista Cultural Centre of the Kwakiutl First Nation in British Columbia (which, in spite of its name, is a museum in every museological respect and a member of the association of museums) or Musée de Mashteuiatsh of the Innu in Pointe-Bleue, Québec.

It is interesting to note that transmitting Amerindian traditions and knowledge is not only the prerogative of First Nations institutions. Offreserve museums have also adopted the "Amerindian way" to appeal to the 
public. The Manitoba Children's Museum at the Forks National Historic Site sees itself as an exploration center for children and families. Even though the museum has its own collection, it is relatively small and mainly made up of facsimiles, enabling manipulation and experiential integration into a different world. Tales, legends, and traditional storytelling are also part of the experience. The archaeology program is a good example of its approach: using games and tactile experiments, educators draw the children into a world predating the arrival of the Europeans and try to get them to imagine life back then. Tales and legends are used to add to their understanding even though the museum is aimed both at families and schoolchildren, it has developed special programs aimed at interpreting intangible First Nations heritage, some of which place particular emphasis on oral tradition. At the museum, children learn through moving, touching, dancing, and singing. Experiencing for themselves is the key to transmission.

For its part, the Manitoba Museum, where in 2001, one in every four visitors under the age of 15 is Native, offers several programs featuring Cree and Inuit know-how, such as history, vocabulary, igloo-building workshops, and more. Given the success of these workshops, the Winnipeg School Division \#1 asked the Museum to develop Aboriginal Education Days for the teachers. The museum answered positively to this request and organized programs aimed at fostering interest and respect for First Nations culture among teachers in the hope that they would continue the work initiated by the museum in the classroom. Through collections and laboratories the museum's viewed indegeous culture, from the traditional, fishing and hunting skills to the women's actual beadmaking. The Manitoba Museum felt that it had the necessary know-how, collections, and experience in presenting indigenous culture to school groups to show teachers how to transmit a basic understanding of Native culture, enabling young people to develop a sense of self-respect and greater respect for others.

\section{Properly representing cultural diversity}

In addition to Aboriginal cultures, Canada is home to many other communities, from Europe and elsewhere, each with traditions they wish to see recognized by their host country. This recognition is even part of the country's immigration policy. Its main purpose is to convey a group's history and dignity, and remind children of their family, cultural, or religious origins - in other words, to signal the presence of a specific culture. Smaller museums are thus spawned by local cultural communities, for whom they are a source of pride. We have said it before: Museums don't acquire collections 
for their own good. The collections are for telling stories, in many cases the core mission of such museums. But before the stories can achieve their purpose, much must be done: documentary research, archiving, film and video production, etc. Memory, we should recall, is intangible, and the tangible is there only to provoke, remind, instruct, and allow us to advance in our inquiries. If it is to be credible, understood, and transmitted, memory must first be collected, studied, and analyzed methodically. As in the 18th century, staff trained in social and human sciences are not legion, and Canada is a vast country. It has therefore been necessary to reinvent ways and means of contacting museologists in the field and giving them at least a minimum of training. Universities have begun to offer programs to address this need, while associations like the CMA have supported regional and local museums. This was the mission undertaken a decade ago by the Cultural Diversity and Museums Committee of the Canadian Museums Association (CMA). This task force, to which I belonged, not only arranged seminars but traveled the length and breadth of the country to meet with those responsible for cultural plurality in museums, evaluating their expertise and offering them further training opportunities, if need be. Work seminars and in-the-field training sessions were held across the country, and various documents and visitor participation models were distributed. Fellowships were offered along with grants to put on exhibits encouraging dialog between communities and the creation of archival and visual documentation. Lastly, various experiences and reflections were collected and published. But the work is far from complete. It is a never-ending process, and museums that wish to transmit knowledge about cultures will have to find ways to attract the trained staff they need to continue the task of documenting these cultures.

\section{Helping contemporary culture flourish: one of Musée de la civilisation's objectives}

Forgive me for stessing once again the role of value transmitters that museums have increasingly assumed. We at Musée de la civilisation de Québec are an excellent example of this. At the crossroads of yesterday and tomorrow, the Museum has great ambitions: to develop knowledge of the past, comprehension of the present, and consciousness of the future. Its thematic range is vast, generous, and all-encompassing, and covers five main themes: body, matter, society, language, and thought. Its approach is multidisciplinary and multifaceted. Since its opening, it has dealt with many conceptual subjects, such as the passage of time, the rituals of death, 
and feminine beauty. As part of this workshop, I will be talking about an exhibition on democracy - a specific form of culture practiced by specific cultures in a precise timeframe and a clearly defined geographical area. This exhibition, entitled Vox populi has been running since October 19, 2005 and is slated to end on April 8, 2007.

\section{Big ideas, big questions}

What do we know about democracy? Can we pledge to protect it? Democracy has not triumphed without a fight nor endured without constant vigilance. And it can only be achieved - and nourished - through the efforts of proud citizens who firmly believe in their rights. Vox populi deals with the encounter between democratic ideals and realities throughout history and the present day. Divided into three thematic areas, the exhibit begins by taking visitors back to the origins of democracy as a political system, illustrating this heritage founded on freedom, equality, and the sovereign power of the citizenry. It goes on to explore the democratic voice in the many places it is freely heard and underscores the importance of the ultimate expression of the equality of all citizens - the right to vote. It concludes by showing that our democratic environment is awash in competing influences and that lofty ideals remain central to the development of our societies.

\section{Sounds and images}

Various singer/songwriters have evoked democracy in their songs, and their words are used to present the exhibition, together with original video documents that deal very movingly with this compelling subject. Four symbolic figures - Luther King, Gandhi, Mandle, and Aung Suu $\mathrm{Kyi}$ - personify the major battles fought in the name of freedom, equality, and justice. Another document underlines how citizens have the right to elect their governments, both here and elsewhere in the world, while a third gives voice to the words of John F. Kennedy and reveals democracy's fragile hold among the great and pressing issues in this globalized world. A final video presents the Québec National Assembly as a place where the democratic voice is free to be expressed. At the end of the exhibition, a young director takes a look at democracy today as well as the democracy we will leave behind for our children in an audiovisual document entitled Letter to my great-great-great-grandchild. 


\section{Food for thought}

The exhibition also features artifacts that bear witness to some of the great moments in democracy. Busts of figures from Antiquity like Demosthenes, Socrates, and Pericles and objects that evoke the birth of modern democracy, such as the Declaration of the Rights of Man and of the Citizen, along with works by thinkers like Montesquieu, Rousseau, and Tocqueville, as well an artistic presentation on the Declaration of the Rights of Man all demonstrate the efforts that have helped emancipate our democratic societies. Other milestones are presented in the form of art and various other objects that illustrate the numerous and constant struggles for democracy: the abolition of slavery, women's obtaining the right to vote, Native claims, the quest for peace and justice throughout the world. The works of artist Dominique Blain provide food for thought on the great number of citizens around the world whose rights have been abused. Lastly, two multimedia games help develop and sharpen visitors' critical thinking with regard to democracy as visitors are invited to vote for the democratic values best corresponding to their view of the world.

\section{Looking ahead to the future...}

Young people are the driving force for change in our high speed world. They are new actors on the democratic stage, and represent the future of democracy. This project targets 18 to 24 -year-olds in particular because they are at the age when one develops a social conscience and an interest in politics. The exhibition aims to make the public at large - and particularly young people - more aware of the importance of living in a democracy. The museum and its partners hope to give them a sense of what it means to participate as a citizen, evoking civic engagement, a sense of responsibility, and human solidarity. Making their voices heard, asking themselves difficult questions, committing themselves publicly, or becoming involved socially are all ways to link representative and participative democracy.

\section{Inventive design and thought-provoking activities}

All manner of means are used to reach out to young visitors. The exhibit design is resolutely contemporary, young, and dynamic, in keeping with the trendy audience the exhibit targets. In terms of layout, the room is divided into three areas with two structures at each end illustrating the encounter between democratic ideals and realities. The space is designed to stimulate with its succession of multimedia modules, video documents, 
and information capsules set to sound.

The theme of democracy is a fertile one on which the Musée de la civilisation invites the public to explore year round through a gamut of cultural activities, including debates, conferences, films, and documentaries. Furthermore, high school groups of all ages are invited to reflect on the impact of democracy on our society in a semi-structured workshop activity. Colleges are also targeted as the exhibition's educational aspects are perfectly suited to college programs. Lastly, on our website, museum visitors can express their thoughts using two multimedia games that help develop visitors' critical thinking with regard to democracy.

\section{Conclusion}

This brief overview of museums, from their origins to the latest postmodern transformations, reveals an institution that keeps time with the society that both feeds and feeds upon it. We have followed the progress of an institution rooted in a precise time and space, from the Enlightenment to the present day, in distinct European and American contexts, where it has constantly changed and evolved to keep pace with social conditions, needs, and lifestyles. We mentioned that the North American museum developed separately from the European museum fairly early on by emphasizing leisure and education in a leisure context. Ties with the local community would also become very important, no doubt due to the need to meet the particular needs of remote communities.

We also know that many North American museums frequently surprise their visitors, and even professionals from Europe. Both sides regularly cross the Atlantic to learn from each other. We further note that museums in Quebec, and in Canada as a whole, tend to focus more on ideas than do their counterparts in Europe, with Musée de la civilisation being a prime example. And were we to actually visit Canadian museums, we would note several further differences from institution to institution because museums - being malleable, mixed, living, and breathing - adapt to the specific needs of communities. The vast, open spaces of North America would therefore seem to suit small, mixed institutions capable of preserving heritage, speaking to citizens, and transmitting - or simply bringing life to - past and current culture. We could have listed many more examples of this adaptation process, for instance by noting the originality and vibrancy of ecomuseums in Quebec, where they originated. But this is neither the time nor the place. 
Nevertheless, I believe that we should start wondering what makes the museum model so exportable and adaptable, in particular the role it plays in the transmission of tangible and intangible culture.

\section{References}

Boas, Franz. 1907. "Some principles of museum administration." Sciences (641): 921-933.

Centlivres, Pierre. 1982. "Des instructions aux collections: la production ethnographique de l'image de l'Orient." In Jacques Hainard et Roland Kaehr, eds., Collection Passion: 33-61. Neuchâtel: Musée d'ethnographie. Copans, Jean and Jean Jamin. 1978. Aux origines de l'anthropologie française; les mémoires de la société des observateurs de l'homme en l'an XIII. Paris: La Sycomore.

Dubé, Philippe and Raymond Montpetit. 1991. "La double genèse de la muséologie québécoise." Internal report, Québec City: Musée de la civilisation.

Leclerc, Gérard. 1979. L'observation de l'homme. Paris: Seuil.

Habernas, Jürgen. 1978. L'espace public. Paris: Payot.

Huyssen, Andreas. 1995. Twilight Memories. Marking Time in a Culture of Amnesia. New York: Routledge.

Mauss, Marcel. 1925. "Essai sur le don. Forme et raison de l'échange dans les sociétés archaïques." L'Année sociologique new series 1: 30-186.

Musée de la Civilisation. 1996. Mission, Concept and Orientations. Québec City: Musée de la Civilisation.

Montpetit, Raymond and Bernard Schiele. 2005. "Mutations et tendances: les musées et l'entrée dans la postmodernité." In Yves Bergeron, ed., Musées et muséologie nouvelles frontières: 227-237. Québec City: Musée de la civilisation, Montréal: Société des musées québécois.

Todorov, Tvetan. 1982. La conquête de l'Amérique, la question de l'autre. Paris: Seuil. 